\title{
EFFECT OF BREED, LIVE WEIGHT ON THE FATTY ACID, AMINO ACID CONTENT AND ON THE BIOLOGICAL VALUE OF BEEF
}

\author{
G. HOLLÓ ${ }^{a *}$, J. CSAPÓb ${ }^{b}$ J. TÖZSÉR ${ }^{a}$, I. HOLLÓb ${ }^{b}$ and E. SzÜCS ${ }^{a}$ \\ ${ }^{a}$ Szent István University, Faculty of Agricultural Sciences, H-2103 Gödöllő, Páter K. u. 2. Hungary \\ ${ }^{\mathrm{b}}$ University of Kaposvár, Faculty of Animal Science, H-7401 Kaposvár, Guba S. u. 40. Hungary
}

(Received: 10 October 2000; accepted: 16 November 2000)

\begin{abstract}
The meat of 21 Hungarian Simmental and 17 Holstein-Friesian cattles was analysed for fatty acid and amino acid content, and also for the biological value of the meat protein. It can be established that the proportion of the saturated and the mono- and polyunsaturated fatty acids compared to each other is not significantly influenced by the breed and the live weight at the various types and weight categories. The increase in the live weight goes together with the increase in the ratio of the monounsaturated fatty acids in the meat in case of both breeds. The amino acid content of the meat was not significantly influenced by the breed, even the live weight didn't demonstrate any effects. The essential amino acid content and the biological value of the meet of the Hungarian Simmental are practically the same as those of the Holstein-Friesian.
\end{abstract}

Keywords: Meat composition, Hungarian Simmental, Holstein-Friesian, amino acid composition, biological value, fatty acid content

According to the lipid-theory worked out in the 50s (KEYS et al., 1957), the cholesterol and the saturated fatty acids content of the animal fats are the key factors to cause arteriosclerosis, high blood-pressure, frequent apoplexy and cardiac infarct in humans (SZAKÁLY, 1995). According to this theory, the cholesterol level of the blood plasma can be reduced by 10 percent with the help of polyunsaturated fatty acids and with the consumption of food containing cholesterol at a decreased level. A positive correlation was established between the blood cholesterol level and arteriosclerosis at the majority of the individuals examined. The theory significantly contributed to the decrease in the use of animal fats in the whole world due to the research studies of the last more than 40 years, proving the multiple susceptibility to the influence of the high cholesterol level of the plasma.

It is widely known that cholesterol is of vital importance for human body, as it is indispensable to the production of sexual hormones, the group of vitamin $\mathrm{D}$, the

* To whom correspondence should be addressed. E-mail: Hollo@ mail.atk.u-kaposvar.hu 
hormones of the adrenal cortex and the bile acids, which are needed to digest fats. The cholesterol molecules infiltrate the cell membrane in order to protect the cell and the body from various exterior effects. The daily cholesterol demand of the human organism is $1000-2000 \mathrm{mg}$, out of which $80 \%$ is synthesised by the organism itself and only $20 \%$ comes from the food, since a part of the food-originated cholesterol leaves the human organism undigested in the excrement.

Concerning the level of cholesterol in animal-originated foods the brain contains $3000-5000 \mathrm{mg} / 100 \mathrm{~g}$, eggs and giblets contain $400-450 \mathrm{mg} / 100 \mathrm{~g}$, and animal fats, meats and meat products contain $80-100 \mathrm{mg} / 100 \mathrm{~g}$ cholesterol. Consequently the organism can take up only a certain proportion of its cholesterol content from meat and animal fats and the major part of our demand is synthesised by the human body.

The fatty acid content of animal fats - as well as cholesterol - and most of the saturated fatty acids are considered to be responsible for provoking the diseases mentioned above. Plants, containing unsaturated vegetable oil in a considerable amount, are considered to be very advantageous in preserving our body's health. KEYS and coworkers (1957) stated that the fatty acid composition is optimal if it contains saturated (SAFA), monounsaturated (MUFA) and polyunsaturated (PUFA) fatty acids at a 1:1:1 proportion. OKUYAMA and IKEMOTO (1999) established that concerning the various illnesses it is not the cholesterol content of the consumed food that is important, but rather the ratio of the n6/n3 PUFA, which has to be kept at the lowest level, and which ratio can be significantly modified by changing the n6 and n3 PUFA content of the fodder. DE DECHERE and co-workers (1998) established that the n3 PUFA content of the sea fish reduces the illnesses of the coronary artery and the reduction can be reached by a consumption of $200 \mathrm{mg} \mathrm{n} 3$ PUFA per day. According to their studies the n3/n6 PUFA ratio of the sea fish did not really influence the diseases mentioned above.

The beef consumption plays an important role in the balanced nutrition in Hungary due to its high nutrition-biological values. The nutritious components of the meat can be digested easily, the biological value of its protein is high, it is an important source of macro and micro elements, and it is also known that almost all of its components can be biologically digested in an excellent way (BRUCE, 1994). However, the protein and the fatty acid content of the meat have to be taken into serious consideration from the point of view of human nutrition. The question of how to preserve your health through your nutrition came into the centre of interest in the last few decades in Hungary, according to which the consumer's demands on the quality of the meat changed as well. Even facing the detriment of tastiness, consumers laid stress on the consumption of non-fatty meats and on fats which contain higher amount of polyunsaturated fatty acids, as these - being described before - play a primary part in preventing heart and vascular system diseases. 
For further support of the meat playing an extremely important part in the human nutrition, the analysis of the fatty acid components of the meat of the most frequently bred cattle of Hungary, the Holstein-Friesian and also the Hungarian Simmental was set as an aim. The ratio of the saturated and unsaturated fatty acids, the amount of protein, amino acid components and biological values were also determined. In our research we would like to present further data for understanding better the composition of meat in order to highlight its role in healthy nutrition.

Unsaturated fatty acids play an important role in creating tastes and aroma (LESEIGNEUR \& GANDEMER, 1991) but on the other hand, the increase of their proportion decreases the oxidative stability of the fats of the muscles and so it favours the deterioration processes (SHAHIDI, 1992). Many studies refer (PERRY et al., 1998) to the fact that the proportion of the saturated and unsaturated fatty acids is significantly influenced by the feeding. According to the research of MANDELL and co-workers (1998), the amount of the polyunsaturated fatty acids can be significantly increased by the fattening on the grazing grounds. MALAU-ADULI and co-workers (1998) doing research on Jersey and Limousine cattle, experienced a significant influence of variety, gender and age concerning the amount of the saturated and unsaturated fatty acids. Similarly, RULE and co-workers (1999) demonstrated differences within breed (Hereford, Limousine, Piemont) according to the fatty acid components of the fats.

HUERTA-LEIDENZ and co-workers (1996), determining the fatty acid components of the fatty tissue of Hereford and Brachmann bulls at different age, could demonstrate significant differences considering only their MUFA level. According to their research work, during the fattening the amount of the saturated fatty acids decreased by $10 \%$ by the increase of age; the MUFA increased significantly, while the PUFA just slightly increased, and the proportion of the 18:2 and 18:3 fatty acids changed as well. KAZALA and co-workers (1999), studying the fatty acid components of the rib muscle and musculus longissimus dorsi of the cross-breed Wagyu cattle, did not find any differences between the MUFA/SAFA proportion of the muscles. They established that the oleic acid content of the fat of the heifer's muscle tissue is higher and its palmitic acid content is lower than those of the bulls at the same age. The amount of the miristic acid increases at both muscles by increasing fat content, while no such relation was found in case of the linoleic acid.

The types of the proteins of the muscles are varying, which significantly influences the amino acid composition of the muscle. The nutritive value of the protein depending on the protein composition of the different tissues is determined above all by the amount and the proportion of the essential amino acids, but it changes by the age and by the live weight, and it can be influenced by the breed as well (PIVA \& GUGLIELMETTI, 1978). The consumer' assessment on the value of the meat should not be rendered independent of the amino acid composition of the proteins, because a 
negative relation was observed (SZÜCS et al., 1985) between the arginine and histidine content of the meat and its tastiness. MOLNÁR and MOLNÁr (1981) studying the amino acid composition of different muscle groups of Hungarian Simmental cattle differing in sex and age established significant differences in case of methionine, lysine and arginine content. They also established that the amino acid composition of the different muscles changes according to their age, and even the amino acid content is influenced by the stress of the muscles as well.

\section{Materials and methods}

During our research meat components of 21 Hungarian Simmental and 17 Holstein-Friesian cows were analysed. The average live weight of the animals was 520 $\mathrm{kg}$, which was ranked between a small weight $(400-500 \mathrm{~kg})$ and a large weight $(501-600 \mathrm{~kg})$ category. When removing the bones after the slaughter, the in-between part of the 11th and 13th rib was removed from the right half part of the animal. After the homogenisation of this slice the determination of the protein content was carried out with the help of a Kjel-Foss fast nitrogen analyser and the fat content was analysed as well. Both determinations were done according to the relevant Hungarian standards. The fatty acid content of the fat was analysed by a Chrompack CP 9000 gas chromatograph; the amino acid content was analysed by a Labor MIM amino acid analyser. When analysing the fatty acid content the results relating to the unknown sample were given as the relative mass percentage of the fatty acid methyl esters (CSAPÓ et al., 1995). During the amino acid determination the protein was hydrolysed in $6 \mathrm{~mol} \mathrm{l}^{-1}$ hydrochloric acid during $24 \mathrm{~h}$, followed by a simultaneous hydrolysis in which the amino acids containing sulphur, were determined in an oxidised form after performic acid oxidation (CSAPÓ et al., 1986). The biological value of the protein was calculated according to the method of MORUP and OLESEN (1976), where the reference basis was the 2:1 mixture of potato and egg white.

The statistical evaluation was carried out with the SPSS 9.0 statistical program with the general linear model of $2 \times 2$ factorial arranged III. Sum of square type, where apart from the two basic effects, the variety, the slaughtering and the weight category were also analysed. When analysing the fatty acid content in the first model the mono fatty acids were grouped according to whether they were once/polyunsaturated or saturated, while in the second model the fatty acids were grouped according to whether they were $\mathrm{n} 3$ or $\mathrm{n} 6$ fatty acids. Three models were set up in the case of the estimation of the amino acids: the first contained only the essential amino acids, the second contained only the non-essential amino acids and the third contained both the essential and nonessential amino acids and also their biological value. 


\section{Results and discussion}

Table 1 shows the fatty acid content of the meat samples from various breeds between $400-500 \mathrm{~kg}$ and 501-600 kg weight categories. Table 2 shows the effects of the variety and the live weight on the fatty acid content, while the amount of the essential and non-essential amino acids is reported in Table 3. The effects of the variety and body weight on the amino acid content and on the biological value were summed up in Table 4.

Table 1

The fatty acid composition of rib samples from different breeds and weight. (Relative percentage of the fatty acids methyl-esters)

\begin{tabular}{|c|c|c|c|c|c|c|c|c|c|c|}
\hline \multirow{3}{*}{ Fatty acids } & \multicolumn{4}{|c|}{ Hungarian Simmental $(n=21)$} & \multicolumn{4}{|c|}{ Holstein-Friesian $(n=17)$} & \multirow{2}{*}{\multicolumn{2}{|c|}{$\begin{array}{l}\mathrm{n}=38 \\
\text { Total }\end{array}$}} \\
\hline & \multicolumn{2}{|c|}{$400-500 \mathrm{~kg}$} & \multicolumn{2}{|c|}{$501-600 \mathrm{~kg}$} & \multicolumn{2}{|c|}{$400-500 \mathrm{~kg}$} & \multicolumn{2}{|c|}{$501-600 \mathrm{~kg}$} & & \\
\hline & mean & SE & mean & SE & mean & SE & mean & SE & mean & SE \\
\hline $10: 0$ & 0.005 & 0.03 & 0.005 & 0.03 & 0.005 & 0.03 & 0.012 & 0.04 & 0.007 & 0.003 \\
\hline $12: 0$ & 0.007 & 0.01 & 0.007 & 0.01 & 0.007 & 0.01 & 0.007 & 0.01 & 0.007 & 0.001 \\
\hline 14:0 & 2.88 & 0.15 & 3.06 & 0.15 & 2.79 & 0.16 & 2.7 & 0.17 & 2.87 & 0.01 \\
\hline $15: 0$ & 0.50 & 0.04 & 0.469 & 0.04 & 0.578 & 0.05 & 0.458 & 0.05 & 0.50 & 0.002 \\
\hline $16: 0$ & 28.38 & 1.69 & 26.92 & 1.62 & 29.03 & 1.79 & 29.73 & 1.89 & 28.39 & 0.86 \\
\hline $16: 1$ & 3.94 & 0.39 & 4.97 & 0.37 & 3.79 & 0.41 & 3.75 & 0.43 & 4.16 & 0.21 \\
\hline $17: 0$ & 1.20 & 0.1 & 1.22 & 0.1 & 1.17 & 0.11 & 1.24 & 0.12 & 1.20 & 0.01 \\
\hline 18:0 & 20.82 & 1.57 & 17.80 & 1.49 & 21.89 & 1.65 & 19.49 & 1.75 & 19.91 & 0.81 \\
\hline $18: 1$ & 38.33 & 1.64 & 42.33 & 1.56 & 37.20 & 1.73 & 39.35 & 1.83 & 39.44 & 0.87 \\
\hline $18: 2 \mathrm{n} 6$ & 2.16 & 0.12 & 1.95 & 0.11 & 1.96 & 0.13 & 1.97 & 0.13 & 2.01 & 0.01 \\
\hline 20:0 & 0.25 & 0.03 & 0.15 & 0.03 & 0.24 & 0.03 & 0.19 & 0.03 & 0.20 & 0.002 \\
\hline $20: 1$ & 0.15 & 0.03 & 0.14 & 0.03 & 0.15 & 0.04 & 0.19 & 0.04 & 0.15 & 0.002 \\
\hline $18: 3$ n3 & 0.52 & 0.05 & 0.43 & 0.05 & 0.36 & 0.05 & 0.32 & 0.06 & 0.41 & 0.003 \\
\hline $20: 3$ n6 & 0.21 & 0.03 & 0.19 & 0.03 & 0.19 & 0.04 & 0.20 & 0.04 & 0.20 & 0.002 \\
\hline $20: 4$ n6 & 0.37 & 0.07 & 0.20 & 0.06 & 0.31 & 0.07 & 0.22 & 0.08 & 0.27 & 0.003 \\
\hline $\begin{array}{l}\text { Saturated fatty } \\
\text { acids }\end{array}$ & 54.15 & 1.92 & 49.73 & 1.83 & 55.81 & 2.03 & 54.01 & 2.15 & 53.23 & 1.02 \\
\hline $\begin{array}{l}\text { Monounsaturated } \\
\text { fatty acids }\end{array}$ & 42.42 & 1.90 & 47.43 & 1.81 & 41.14 & 2.00 & 43.28 & 2.13 & 43.75 & 1.02 \\
\hline $\begin{array}{l}\text { Polyunsaturated } \\
\text { fatty acids }\end{array}$ & 3.26 & 0.18 & 2.77 & 0.17 & 2.82 & 0.19 & 2.72 & 0.20 & 2.90 & 0.01 \\
\hline$\sum$ n6 & 2.74 & 0.19 & 2.34 & 0.18 & 2.46 & 0.20 & 2.40 & 0.22 & 2.49 & 0.01 \\
\hline
\end{tabular}


Table 2

The effects of the breed and the live weight on the fatty acids composition

\begin{tabular}{lccc}
\hline Fatty acid methyl ester $(\%)$ & Breed & Live weight & Breed $\times$ live weight \\
\hline $10: 0$ & NS & NS & NS \\
$12: 0$ & NS & NS & NS \\
$14: 0$ & NS & NS & NS \\
$15: 0$ & NS & NS & NS \\
$16: 0$ & NS & NS & NS \\
$16: 1$ & NS & NS & NS \\
$17: 0$ & NS & NS & NS \\
$18: 0$ & NS & NS & NS \\
$18: 1$ & NS & NS & NS \\
$18: 2$ n6 & NS & $* *$ & NS \\
$20: 0$ & NS & NS & NS \\
$20: 1$ & NS & NS & NS \\
$18: 3$ n3 & $* *$ & NS & NS \\
$20: 3$ n6 & NS & NS & NS \\
$20: 4$ n6 & NS & NS & NS \\
Saturated fatty acids & NS & NS & NS \\
Monounsaturated fatty acids & NS & NS & NS \\
Polyunsaturated fatty acids & NS & & \\
$\Sigma$ n6 & NS & & \\
\hline
\end{tabular}

NS: Not significant

** $\mathrm{P}<0.01$

In the first model neither the variety nor the weight category had any effects on the fatty acid content of the fat. Arachinic acid (20:0) and linolenic acid (18:3n3) turned out account for the greatest proportion $\left(\mathrm{R}^{2}=0.213\right.$, and $\left.\mathrm{R}^{2}=0.201\right)$ in the calculation of the total variance. On the other hand in case of the second model both the variety and the live weight possessed significant impacts. As it can be seen in Table 1, the monounsaturated fatty acid, the oleic acid, and two saturated fatty acids, the palmitic acid and the stearic acid give $90 \%$ of the whole fatty acid content. The ratio of the PUFA/SAFA is an average of 0.06 , which seems to be the most favourable in the small weight Hungarian Simmental group. The increase in the live weight at both breeds goes together with the increase in the monounsaturated fatty acid ratio and with the decrease in the amount of the saturated and unsaturated fatty acids. In the latter case an increase concerning the $\mathrm{n} 3$ fatty acids can only be experienced at the great weight HolsteinFriesian category. According to the data given in Table 2, only the arachidonic acid shows significant differences concerning the variety and only the linolenic acid has similar effects concerning the live weight. 
Table 3

The amino acid composition of rib samples from different breeds and weight

\begin{tabular}{|c|c|c|c|c|c|c|c|c|c|c|}
\hline \multirow{3}{*}{$\begin{array}{l}\text { Amino acids } \\
\mathrm{g} / 100 \mathrm{~g} \text { protein }\end{array}$} & \multicolumn{4}{|c|}{ Hungarian Simmental } & \multicolumn{4}{|c|}{ Holstein-Friesian } & \multirow{2}{*}{\multicolumn{2}{|c|}{$\begin{array}{l}\mathrm{n}=38 \\
\text { Total }\end{array}$}} \\
\hline & \multicolumn{2}{|c|}{$400-500 \mathrm{~kg}$} & \multicolumn{2}{|c|}{$501-600 \mathrm{~kg}$} & \multicolumn{2}{|c|}{$400-500 \mathrm{~kg}$} & \multicolumn{2}{|c|}{$501-600 \mathrm{~kg}$} & & \\
\hline & mean & SE & mean & SE & mean & SE & mean & $\mathrm{SE}$ & mean & SE \\
\hline $\begin{array}{l}\text { Essential amino } \\
\text { acids }\end{array}$ & 47.2 & 0.39 & 46.8 & 0.3 & 46.7 & 0.4 & 46.2 & 0.4 & 46.7 & 0.20 \\
\hline Arginine & 6.11 & 0.15 & 6.08 & 0.1 & 6.02 & 0.1 & 5.9 & 0.1 & 6.04 & 0.00 \\
\hline Phenylalanine & 4.14 & 0.08 & 4.12 & 0.0 & 4.19 & 0.0 & 4.23 & 0.0 & 4.17 & 0.00 \\
\hline Histidine & 4.24 & 0.11 & 4.12 & 0.1 & 3.92 & 0.1 & 3.96 & 0.1 & 4.07 & 0.00 \\
\hline Isoleucine & 4.23 & 0.11 & 4.26 & 0.1 & 4.4 & 0.1 & 4.36 & 0.1 & 4.31 & 0.00 \\
\hline Leucine & 8.22 & 0.10 & 8.16 & 0.1 & 8.34 & 0.1 & 7.99 & 0.1 & 8.18 & 0.00 \\
\hline Lysine & 9.25 & 0.17 & 9.09 & 0.1 & 9.09 & 0.1 & 8.7 & 0.1 & 9.05 & 0.00 \\
\hline Methionine & 1.65 & 0.15 & 1.68 & 0.1 & 1.73 & 0.1 & 1.44 & 0.1 & 1.63 & 0.00 \\
\hline Threonine & 4.91 & 0.01 & 4.87 & 0.1 & 4.58 & 0.1 & 4.45 & 0.1 & 4.72 & 0.00 \\
\hline Valine & 4.52 & 0.15 & 4.43 & 0.1 & 4.49 & 0.1 & 5.18 & 0.1 & 4.62 & 0.00 \\
\hline $\begin{array}{l}\text { Non-essential } \\
\text { amino acids }\end{array}$ & 51.6 & 0.42 & 52.0 & 0.4 & 52.1 & 0.4 & 52.4 & 0.4 & 52.0 & 0.21 \\
\hline Alanine & 6.64 & 0.27 & 6.19 & 0.2 & 6.92 & 0.2 & 6.91 & 0.3 & 6.63 & 0.14 \\
\hline Aspartic acid & 8.92 & 0.21 & 9.08 & 0.2 & 8.82 & 0.2 & 8.71 & 0.2 & 8.9 & 0.10 \\
\hline Cystine & 0.85 & 0.11 & 0.98 & 0.1 & 0.99 & 0.1 & 1.19 & 0.1 & 0.99 & 0.00 \\
\hline Glycine & 5.65 & 0.31 & 6.18 & 0.3 & 6.62 & 0.3 & 7.03 & 0.3 & 6.32 & 0.17 \\
\hline Glutamic acid & 16.8 & 0.22 & 17.0 & 0.2 & 16.4 & 0.2 & 15.8 & 0.2 & 16.6 & 0.13 \\
\hline Proline & 4.97 & 0.25 & 4.99 & 0.2 & 4.86 & 0.2 & 5.30 & 0.2 & 5.02 & 0.13 \\
\hline Serine & 4.05 & 0.09 & 4.07 & 0.1 & 3.77 & 0.1 & 3.83 & 0.1 & 3.94 & 0.00 \\
\hline Tyrosine & 3.77 & 0.10 & 3.51 & 0.1 & 3.70 & 0.1 & 3.65 & 0.1 & 3.65 & 0.00 \\
\hline Biological value & 74.4 & 3.47 & 73.0 & 3.3 & 73.8 & 3.6 & 79.1 & 3.8 & 74.8 & 1.75 \\
\hline
\end{tabular}

The analysis of the 3-model set up for the evaluation of the amino acid results shows that the impact of the variety seemed to be significant at the first model, containing essential amino acids, while concerning the other two models neither the impact of the variety nor the live weight seemed to be significant. The interaction of [variety $\times$ live weight] could not be demonstrated in either model. From the essential amino acids it was the threonine $\left(\mathrm{R}^{2}=0.290\right)$ and the valine $\left(\mathrm{R}^{2}=0.287\right)$ which mostly took part in creating the variance, so almost $50 \%$ of the total variance was given by these two essential amino acids. Out of the non-essential amino acids glutamic acid $\left(\mathrm{R}^{2}=0.326\right)$, glycine $\left(\mathrm{R}^{2}=0.224\right)$ and serine $\left(\mathrm{R}^{2}=0.188\right)$ played a significant role within the total variance. According to the data in Table 3, the amount of the essential amino acids in the case of the Hungarian Simmental is bigger in both weight categories than in 
the Holstein-Friesian's group. Considering all the individuals, the biological value is 74.89 , which corresponds very well to the value of about 72-76 given by the literature (HEGEDÚs et al., 1981; ENSMINGER et al., 1995). It deserves attention that the biological value is 79.19 at the heavier (501-600 kg) Holstein-Friesian cattle. Table 4 shows that in case of the amino acid content of the meat of the two breeds, a significant difference was reported in the essential amino acids such as histidine, threonine and valine, while considering the non-essential amino acids it was glycine, glutamic acid and serine which produced no significant differences. Between the live weight categories only leucine produced no significant difference, and regarding the interaction of the two main influences it was valine, turned out to be significant.

Table 4

The effects of the breed and the live weight on the amino acid composition and the biological value

\begin{tabular}{lccc}
\hline Amino acids (g/100 g protein) & Breed & Live weight & Breed $\times$ live weight \\
\hline Essential amino acids & NS & NS & NS \\
Arginine & NS & NS & NS \\
Phenylalanine & NS & NS & NS \\
Histidine & $*$ & NS & NS \\
Isoleucine & NS & $*$ & NS \\
Leucine & NS & NS & NS \\
Lysine & NS & NS & NS \\
Methionine & NS & NS & NS \\
Threonine & $* * *$ & NS & $*$ \\
Valine & $*$ & NS & NS \\
Non-essential amino acids & NS & NS & NS \\
Alanine & NS & NS & NS \\
Aspartic acid & NS & NS & NS \\
Cystine & NS & NS & NS \\
Glycine & $* *$ & NS & NS \\
Glutamic acid & $* * *$ & NS & NS \\
Proline & NS & NS & NS \\
Serine & $* *$ & NS & NS \\
Tyrosine & NS & & NS \\
Biological value & &
\end{tabular}

NS: Not significant

$* \mathrm{P}<0.05 ; * * \mathrm{P}<0.01 ; * * * \mathrm{P}<0.001$ 
Comparing the fatty acid content of the beef with the fatty acid content of the pork (CSAPÓ et al., 1999; HUGO et al., 1999), it can be pointed out that the amount of the saturated fatty acids is larger in the analysed meat concerning all the fatty acids, while the oleic acid and linoleic acid content of the pork fat are substantially larger than that of the meat analysed. Comparing the fatty acid content (HERNANDEZ et al., 1998) of the musculus longissimus dorsi of the pork with that of the rib, it can be ascertained that it is richer in saturated fatty acids; the oleic acid content is approximately the same, while among the polyunsaturated fatty acids the linolenic acid content is seven times higher and the arachidonic acid content is fifteen times higher than that of the analysed meat. It can be stated as a summary that the saturated fatty acid content of the analysed meat is higher and its unsaturated fatty acid content is lower than that of the lard and the pork.

\section{Conclusions}

Studying the fatty acid content of the cattle meat of various breeds and live weight we established that according to the valuation of the GLM model the ratio of the saturated and mono- and polyunsaturated fatty acids compared to each other is not significantly influenced by the breed and the live weight in most cases. The ratio of the monounsaturated fatty acid content increases in the meat in line with the increase in the live weight. Regarding the achievements of our research, the amino acid content of the meat in the case of most amino acids is not significantly influenced by the breed and also there is no pronounced impact of the live weight. The essential amino acid content and the biological value of the meat of the Hungarian Simmental individuals practically show no difference from the meat of the Holstein-Friesian breed.

\section{References}

BRUCE, A. (1994): Opening lecture. 45th Annual meeting of the European Association for Animal Production, Edinburgh, Scotland, September 2-10.

CSAPó, J., CSAPó-KISS, Zs. \& TÓTH-PÓSFAI, I. (1986): Optimisation of hydrolysis at determination of amino acid content in food and feed products. Acta Alimentaria, 15, 3-21.

Csapó, J., Stefler, J., Martin, T. G., Makrai, S. \& Csapó-Kiss, Zs. (1995): Composition of mares' colostrum of milk. Fat content, fatty acid composition and vitamin content. Int. Dairy J., 5, 393-402.

Csapó, J., Húsvéth, F., Csapó-Kiss, Zs., Horn, P., Házas, Z., Varga-Visi, É. \& Bő́cs, K. (1999): KülönbözŐ fajtájú sertések zsírjának zsírsavösszetétele és koleszterintartalma. (Fatty acid and cholesterol composition of the lard of different genotypes of swine.) Acta Agraria Kaposváriensis, 3, 1-14.

De Dechere, E. A., Korver, O. M., Verscherren, P. M. \& Katan, M. B. (1998): Health aspects of fish and $\mathrm{n} 3$ polyunsaturated fatty acids from plant and marine origin. Eu. J. clin. Nut., 52, 749-753.

Ensminger, M. E., Ensminger, A. H., Conlande, J. E. \& Robson, J. R. K. (1995): The concise encyclopedia of food and nutrition. CRC Press LLC, Boca Raton, pp. 325-332. 
HegedÜs, M., KRALOVÁNSZKY, U. P. \& MÁTRAI, T. (1981): A takarmányfehérjék minösítése. (Qualification of feed proteins.) Mezőgazdasági Kiadó, Budapest, pp. 44-63.

HeRnANDEZ, P., NAVARRO, J. L. \& TOLDRA, F. (1998): Lipid composition and lipolytic enzyme activities in porcine skeletal muscles with different oxidative pattern. Meat Sci., 49, 1-10.

Huerta-Leidenz, N. O., Cross, H. R., SAvell, J. W., Lunt, D. K., BAKER, J. F. \& Smith, S. B. (1996):. Fatty acid composition of subcutaneous adipose tissue from male calves at different stages of growth. J. Anim. Sci., 74, 1256-1264.

Hugo, A., Osthoff, G. \& Jooste, P. J. (1999): Technological and chemical quality of pig adipose tissue: effect of backfat thickness. Proceedings of 45th ICOMST, pp. 494-495.

Kazala, E. C., Lozeman, F. J., Mir, P. S., Laroche, A., Bailey, D. R. C., \& Weselake, R. J. (1999): Relationship of fatty acid composition to intramuscular fat content in beef from crossbred wagyu cattle. J. Anim. Sci., 77, 1717-1725.

Keys, A., Anderson, J. T. \& Grande, F. (1957): Prediction of serum cholesterol responses of man to changes in fats in the diet. Lancet, 2, 959-966.

LESEIGNEUR, M. A. \& GANDEMER, G. (1991): Lipid composition of pork muscle as related to metabolic types of fibres. Meat Sci., 29, 229-241.

Malau-Aduli, A. E. O., Siebert, B. D., Bottema, C. D. K. \& Pitchford, W. S. (1998): Breed comparison of the fatty acid composition of muscle phospholipids in jersey and in limousine cattle. $J$. Anim. Sci., 76, 766-773.

Mandell, J. B., BuChanAN-SMith, J. G. \& CAMPBELl, C. P. (1998): Effects of forage vs. grain feeding on carcass characteristics, fatty acid composition, and beef quality in limousine cross steers when time on feed is controlled. J. Anim. Sci., 76, 2619-2630.

MOLNÁR, J. \& MoLNÁR, A. (1981): Adatok a magyartarka húsának aminosav összetételéhez. (Data on the amino acid composition of the meat of the Hungarian Simmental.) Élelmiszeripari Föiskola Tudományos Közlemények, 9, 63-68.

MORUP, K. \& OlESEN, E.S. (1976): New method for prediction of protein value from essential amino acid pattern. Nutr. Rep. Int., 13, 355-365.

OкuYама, H. \& Iкемото, А. (1999): Needs to modify the fatty acid composition of meats for human health. Proceedings of 45th ICOMST, pp. 638-640.

Perry, D., Nicholls, P. J. \& ThOMPSON, J. M. (1998): The effect of sire breed on the meeting point and fatty acid composition of subcutaneous fat in steers. J. Anim. Sci., 76, 87-95.

Piva, G. \& GuglielmetTi, D. (1978): Meat amino acid composition of calves and steers slaughtered between $200 \mathrm{~kg}$ and $500 \mathrm{~kg}$ live weight. - in: De BoER, H., \& MARTIN, J.: Pattern of growth and development in cattle. Nijhoff, Hague - Boston - London, pp. 178-185.

Rule, D. C., ShorT, R. E., Grosz, M. D. \& MACNeIL, M. D. (1999): Breed effects on cholesterol and fatty acids in longissimus muscle of hereford, limousine and pied montese $F_{2}$ crossbred cattle as slaughtered. Proceedings of ASAS-ADSA Annual Meeting, Indianapolis, p. 166.

SHAHIDI, F. (1992): Prevention of lipid oxidation in muscle foods by nitrite \& nitrate-free composition. - in: St ANGelo, A. J. (Ed.) Lipid oxidation in food. American Chemical Society, Washington, DC, pp. 161-182.

SZAKÁLY, S. (1995): A vaj a lipid-elmélet szorításában. (Butter in the grip of lipid-theory.) Tejgazdaság, 55, 12-21.

Szű́cs, E., VotisKy, L., CsiBA, A. \& Ács, I. (1985): Adatok a növendékbikák húsának aminosav összetételéhez és biológiai értékéhez. (Data on the amino acid composition and the biological value of the meat of young bulls.) Húsipar, 24, 156-159. 